\title{
CHARACTERIZING THE VAQUEJADA HORSE HERD IN THE BRAZILIAN STATE OF PERNAMBUCO
}

\author{
CARACTERIZAÇÃO DO REBANHO PERNAMBUCANO DE EQUINOS DE \\ VAQUEJADA
}

\author{
Paula Barbosa TORRES ${ }^{1}$; Juliano Martins SANTIAGO ${ }^{2}$; \\ Jorge Eduardo Cavalcante LUCENA ${ }^{3}$; Gustavo Simões LIMA ${ }^{4}$; \\ Daniel Anderson de Souza MELO ${ }^{5}$; Alisson Vinícius Mota MORAES ${ }^{6}$; \\ Andreza Correia da SILVA ${ }^{5}$; Diogo Gutemberg Nascimento BEZERRA
}

1. Universidade Federal Rural de Pernambuco - UFRPE, Engenharia Agrícola, Programa de Pós-Graduação em Ciência Animal e Pastagens, Garanhuns, PE, Brasil. Bolsista CAPES. paulla_03@hotmail.com; 2. Universidade Federal Rural de Pernambuco, Unidade Acadêmica de Serra Talhada - UFRPE, Serra Talhada, PE, Brasil; 3. Universidade Federal Rural de Pernambuco, Unidade Acadêmica de Garanhuns - UFRPE, Garanhuns, PE, Brasil; 4. Universidade Federal Rural de Pernambuco, Medicina Veterinária, Unidade Acadêmica de Garanhuns - UFRPE, Garanhuns, PE, Brasil; 5. Universidade Federal Rural de Pernambuco, Unidade Acadêmica de serra Talhada - UFRPE, Serra Talhada, PE, Brasil; 6. Universidade Federal Rural de Pernambuco, Unidade Acadêmica de Garanhuns UFRPE, Garanhuns, PE, Brasil.

\begin{abstract}
This study aimed to determine the age groups, breeds, and morphological characteristics of horses used in vaquejada competitions, as well as to define how often the animals compete, the results achieved in the contests, and the duration of training. A sample of 1,271 horses used in vaquejada competitions was employed in the study. The first step consisted in interviewing owners to obtain information on the age and breed of the horses, vaquejada circuits in which they compete, frequency of competition in vaquejada, results reached in the trials, and training duration per month, week, and day. The second step obtained 15 linear measurements and calculated eight morphometric indices. The data obtained from the interviews were submitted to descriptive statistical analyses. The linear measurements and morphometric indices were used to compare sexes using a completely randomized experimental design. The results showed that $80.3 \%$ of the vaquejada horses were between four and ten years old and that $89 \%$ of the animals were of the Quarter Horse. The morphometric measures showed that stallions had higher height at withers, back, and croup and wider heads, chest, and croup than mares and geldings. On the other hand, among the eight indices calculated, only the value of the height at the chest of the stallions was higher than the mean values in mares and geldings. It was found that $79.7 \%$ of the horses took part in two to four vaquejada trials a month while $93.3 \%$ of the animals underwent fitness training 12 months a year. The results show a predominance of Quarter Horses in the vaquejada contests in Pernambuco and that the trials require the selection of physically larger and stronger stallions. In addition, the animals are submitted to intense training and competition routines.
\end{abstract}

KEYWORDS: Competitions. Equine. Equus caballus. Morphometric indices. Training.

\section{INTRODUCTION}

According to Lima et al. (2006), vaquejadas had been practiced in Brazil since the $18^{\text {th }}$ century, although the first record of their existence dates to the late $19^{\text {th }}$ century. However, the trials took place in ranches and farms with no attendance of people stranger to the owners. Events open to the public appeared in the $20^{\text {th }}$ century in the Brazilian Northeast region and have experienced constant growth over the years. Starting in 1980, the rules became more defined and prizes were awarded to competitors.

In Brazil, the recognition of vaquejada as a sports activity and of vaqueiros as athletes was officialized through Federal Law no. 10,220 of
April 11 $11^{\text {th }}, 2001$ (FELIX; ALENCAR, 2011). In 2016, the sport was legally acknowledged as intangible cultural heritage by Law 13,364/2016.

Throughout Brazil, vaquejada has an estimated three million fans with over two thousand contests, 400 of which are considered official. The activity drives BRL 164 million per year and permanently employs 1,430 people. Within the sports segment, $9.3 \%$ of athlete horse owners in Brazil raise animals for vaquejada. That means the equine herd for vaquejada is the third largest in the country, accounting for $12.9 \%$ of the national sports horse herd (LIMA et al., 2016).

The runs are performed by two athletes, who ride horses to chase a bovine, which often charges out of the corral at speed, to attempt to drop it to the 
ground within the parallel track lines usually $9 \mathrm{~m}$ wide. Each vaqueiro plays a specific role. The esteira - or trailing - vaqueiro is in charge of positioning the animal in the track and of grabbing its tail and quickly handing it to the partner. After the bovine goes to the ground within the track limits, the esteira is also responsible for not allowing the animal to go over the boundaries when standing up. The puxador - or leading - vaqueiro is in charge of pulling the bovine by its tail and dropping it to the ground within the track limits (ABVAQ, 2017).

In order to make the contests more homogeneous and aligned with animal well-being, certain criteria were established: The bovine must weigh at least 12 arrobas - each arroba being equivalent to $15 \mathrm{~kg}$ - for the qualifying rounds and 16 arrobas for the final contests; mandatory tail protection for all bovines; and a minimum sand depth of $40 \mathrm{~cm}$ in the area where the bovine is dropped (ABVAQ, 2017).

Although vaquejada is socioeconomically important for the country, the few studies that have dealt with the subject pointed out the lack of knowledge and professional training that lead to inadequate animal management and training (LAGE et al., 2007; LOPES et al., 2009; PIMENTEL et al., 2011; MELO et al., 2011; SOUSA, 2012).

Moreover, considering the horse to be the athlete of vaquejada, the correlation between overall appearance and function must be taken into account since the main use of the animals is based on their locomotion capacity. Hence, the need to associate horse form and function justifies carrying out objective morphometric assessments (PIMENTEL et al., 2011). Based on data from measurements of different parts of the animals, several authors have sought to establish indices able to characterize the horses phenotypically and to correlate them to their economic role.

This study aimed to determine the age groups, breeds, and morphological characteristics of horses used in vaquejada competitions in the Brazilian state of Pernambuco, as well as to define how often the animals compete, the results achieved in the contests, and the duration of training sessions.

\section{MATERIAL AND METHODS}

The study was approved by the Ethics Committee on Animal Use under license 053/2016 and was developed in vaquejada contests in the sertão and agreste regions of Pernambuco. A random sample of 1,271 vaquejada horses was chosen comprising stallions, mares, and geldings of different breeds and age groups and competing in either puxador or esteira roles. Data were collected in two steps:

The first step consisted of an interview with horse owners using a pre-defined form to obtain information on the role the animals play in the vaquejada (esteira, right-side puxador, or left-side puxador), age, breed, sex, vaquejada circuits where they compete, frequency of competition, results achieved, and monthly, weekly, and daily duration of training.

The second step consisted of 15 linear measurements of the horses using a measuring stick and measuring tape with $0.01 \mathrm{~cm}$ precision. The animals were measured while standing square on a level wooden board. The linear measurements were taken according to the methodology described by Bretas et al. (2003):

- Height at withers: distance between the free ends of the spinous process of the $5^{\text {th }}$ or $6^{\text {th }}$ thoracic vertebrae and the ground;

- Height at back: distance between the free ends of the spinous process of the $12^{\text {th }}$ or $13^{\text {th }}$ thoracic vertebrae and the ground;

- Height at croup: distance between the highest point of the lumbosacral transitional vertebra and the ground;

- Height at side of the back: distance between the spinous processes of the $12^{\text {th }}$ and $13^{\text {th }}$ thoracic vertebrae and the xiphoid process of the sternebrae;

- Head length: distance between the front of the muzzle and the back of the neck;

- Neck length: distance between the cranial portion of the lateral mass of the atlas and the cranial crest of the medium third of the supraspinatus muscle;

- Back-loin length: distance between the spinous processes of the $8^{\text {th }}$ thoracic and $6^{\text {th }}$ lumbar vertebrae;

- Croup length: distance between the cranial portion of the lateral surface of the iliac tuberosity and the ischial tuberosity;

- Shoulder length: distance between the central portion of the proximal end of the scapular cartilage and the center of the scapulohumeral joint;

- Body length: distance between the cranial crest of the scapulohumeral joint and the ischial tuberosity; - Head width: distance between the ends of the rightand left-side frontal zygomatic or supraorbital processes;

- Chest width: distance between the greater tubercle of the left and right humerus bones;

- Croup width: distance between the lateral ends of the right- and left-side iliac tuberosities;

- Thoracic circumference: The measuring tape surrounded the thorax while touching the free end of 
the spinous process of the $11^{\text {th }}$ thoracic vertebra and the region of the $9^{\text {th }}$ intercostal space;

- Cannon circumference: The measuring tape surrounded the medial third of the third metacarpal bone.

Next, the linear measurements were used to calculate eight morphometric indices described and verified by Oom and Ferreira (1987), Ribeiro (1989), and Torres and Jardim (1992):

- Approximate calculated weight $=$ (thoracic circumference $)^{3}$ x $80(\mathrm{~kg})$

- Height at chest $=$ height at withers - height at side of the back (m)

- Chest index $(\mathrm{CI})=$ height at side of the back height at chest $(\mathrm{m})$

CI $>0$ : animal close to the ground

$\mathrm{CI}<0$ : animal away from the ground

- Body index (BI) = body length/thoracic circumference (non-dimensional)

$\mathrm{BI}>90$ : slender

$0.86 \mathrm{BI}<0.89$ : mediolinear

$\mathrm{BI}<0.85$ : compact

- Dactyl-thoracic index (DTI) = cannon circumference/thoracic circumference (nondimensional)

DTI $>0.108$ : hypermetric

DTI $<0.108$ : eumetric

$\mathrm{DTI}<0.105$ : hypometric

Conformation index = (thoracic circumference $)^{2} /$ height at withers (non-dimentional)

The value of 2.1125 is ideal for saddle horses

- Load index $1=\left((\text { thoracic circumference })^{2} \mathrm{x}\right.$ 56)/height at withers $(\mathrm{kg}))$

- Load index $2=\left((\text { thoracic circumference })^{2} \mathrm{x}\right.$ 95)/height at withers $(\mathrm{kg}))$

The data regarding animal age, breed, role performed in the vaquejada, circuits where they compete, frequency of contest attendance, results achieved in the trials, and training duration were submitted to descriptive statistical analyses using the statistical software GraphPad Instat (version 3.06).

The linear measurements and morphometric indices were used to compare sexes using a completely randomized experimental design comprising three treatments: stallions, mares, and geldings.

The results of linear measurements and five morphometric índices (approximate calculated weight, height at chest, chest index, body index and dactyl-thoracic index) did not pass the normality test, being submitted to the Kruskal-Wallis test and the means compared by the Dunn test $(\mathrm{p}<0.05)$.
The results of the three morphometric indices that presented normal distribution (conformation index, load index 1 and load index 2) were submitted to analysis of variance and the means were compared by Tukey's test at 5\% probability with the use of the statistical software SISVAR (version 5.60). The statistical model used was:

$\mathrm{y}_{\mathrm{ik}}=\mu+\mathrm{T}_{\mathrm{i}}+\varepsilon_{\mathrm{ik}}$

in which $\mathrm{y}_{\mathrm{ik}}=$ dependent variables; $\mu=$ overall mean; $\mathrm{Ti}=$ effect of the sexes (stallions, mares, and geldings); and $\varepsilon_{\mathrm{ik}}=$ residual random error.

\section{RESULTS}

The vaquejada competitions in Pernambuco featured a broad age variation among the athlete horses, with animals between two and 22 years old taking part in contests. However, the number of foals between two and tree years old was small at nine and 39 specimens, respectively. Likewise, the number of older animals, between 11 and 22 years old, added up to only 194 horses. Most of the horses studies (988 animals) were between four and ten years old.

The most common breeds in the vaquejadas were Quarter Horse (89\%) and crossbred Quarter Horse (9.3\%). Appaloosa, English Thoroughbred, and Paint Horse accounted for only $1.7 \%$ of the animals.

The morphometric measures showed that stallions had higher height at the withers, back, and croup and head width than mares and geldings (Table 1).

Nonetheless, the approximate calculated weight of stallions of $448.3 \mathrm{~kg}$ did not differ from that calculated for mares and geldings of 455.5 and $444.5 \mathrm{~kg}$, respectively (Table 2).

Among the eight parameters calculated from the linear measurements, only the value of height at chest of the stallions $(0.814 \mathrm{~m})$ was higher than that of mares and geldings of 0.799 and $0.802 \mathrm{~m}$, respectively. The opposite was found for chest index, for which the mares $(-0.181 \mathrm{~m})$ and geldings $(-0.184 \mathrm{~m})$ had higher averages than the stallions ($0.194 \mathrm{~m})$.

In addition, the stallions had higher mean body index value than the geldings. The dactylthoracic index of 0.1069 found in the mares was lower than the averages of stallions and geldings of 0.1103 and 0.1107 , respectively. On the other hand, the mean values of conformation index, load index 1 , and load index 2 of the mares were higher than 
those of stallions and geldings.

Of the 1,271 horses evaluated, 891 competed as puxador and 380 , as esteira. $3.3 \%$ of the horses took part in vaquejada trials less than once a month, $16.9 \%$ competed once a month, $34.1 \%$ competed twice a month, $20.6 \%$ competed three times a month, and $25.0 \%$ attended vaquejadas every weekend. In addition, $49.2 \%$ of the animals competed in both official and unofficial competitions. $44.5 \%$ competed only in official trials, and $6.3 \%$ took part only in unofficial contests, commonly called bolões (polls).

Table 1. Linear measures expressed in meters (mean \pm standard deviation) of stallions, mares, and geldings competing in vaquejada contests in the Brazilian state of Pernambuco

\begin{tabular}{lllll}
\hline Measures & Stallions & Mares & Geldings & P-value \\
\hline HWIT & $1.505 \pm 0.05^{\mathrm{a}}$ & $1.489 \pm 0.04^{\mathrm{b}}$ & $1.498 \pm 0.04^{\mathrm{ab}}$ & 0.0018 \\
HBAC & $1.433 \pm 0.04^{\mathrm{a}}$ & $1.416 \pm 0.04^{\mathrm{b}}$ & $1.419 \pm 0.04^{\mathrm{b}}$ & 0.0003 \\
HCRO & $1.517 \pm 0.04^{\mathrm{a}}$ & $1.504 \pm 0.04^{\mathrm{b}}$ & $1.502 \pm 0.04^{\mathrm{b}}$ & 0.0036 \\
HSBA & $0.620 \pm 0.02$ & $0.618 \pm 0.02^{\mathrm{a}}$ & $0.618 \pm 0.02$ & 0.4083 \\
LHEA & $0.581 \pm 0.02^{\mathrm{a}}$ & $0.575 \pm 0.02^{\mathrm{b}}$ & $0.580 \pm 0.02^{\mathrm{ab}}$ & 0.0239 \\
LNEC & $0.619 \pm 0.04^{\mathrm{a}}$ & $0.607 \pm 0.04^{\mathrm{b}}$ & $0.613 \pm 0.04^{\mathrm{b}}$ & 0.0203 \\
LSHO & $0.532 \pm 0.03$ & $0.532 \pm 0.03$ & $0.529 \pm 0.03$ & 0.6047 \\
LBL & $0.541 \pm 0.05$ & $0.549 \pm 0.05$ & $0.540 \pm 0.05$ & 0.0931 \\
LCRO & $0.514 \pm 0.03$ & $0.513 \pm 0.03$ & $0.512 \pm 0.03$ & 0.9602 \\
LBOD & $1.582 \pm 0.06^{\mathrm{a}}$ & $1.579 \pm 0.06^{\mathrm{a}}$ & $1.563 \pm 0.06^{\mathrm{b}}$ & 0.0023 \\
CTHO & $1.775 \pm 0.05^{\mathrm{ab}}$ & $1.784 \pm 0.06^{\mathrm{a}}$ & $1.769 \pm 0.06^{\mathrm{b}}$ & 0.0341 \\
CCAN & $0.197 \pm 0.01^{\mathrm{a}}$ & $0.192 \pm 0.01^{\mathrm{b}}$ & $0.197 \pm 0.01^{\mathrm{a}}$ & $<0.0001$ \\
WHEA & $0.201 \pm 0.01^{\mathrm{a}}$ & $0.194 \pm 0.01^{\mathrm{b}}$ & $0.198 \pm 0.01^{\mathrm{b}}$ & $<0.0001$ \\
WCHE & $0.410 \pm 0.04$ & $0.401 \pm 0.04$ & $0.400 \pm 0.03$ & 0.1076 \\
WCRO & $0.515 \pm 0.03^{\mathrm{b}}$ & $0.529 \pm 0.04^{\mathrm{a}}$ & $0.518 \pm 0.03^{\mathrm{b}}$ & $<0.0001$ \\
\hline
\end{tabular}

HWIT = height at withers; HBAC = height at back; HCRO = height at croup; HSBA = height at side of the back; LHEA = head length; $\mathrm{LNEC}=$ neck length; $\mathrm{LSHO}=$ shoulder length; $\mathrm{LBL}=$ back-loin length; $\mathrm{LCRO}=$ croup length; $\mathrm{LBOD}=$ body length; $\mathrm{CTHO}=$ thorax circumference; $\mathrm{CCAN}=$ cannon circumference; $\mathrm{WHEA}=$ head width; $\mathrm{WCHE}=$ chest width; $\mathrm{WCRO}=$ croup width.

Different letters in the lines differ according to Dunn's test $(\mathrm{P}<0.05)$.

Table 2. Morphometric indices (mean \pm standard deviation) of stallions, mares and geldings competing in vaquejada contests in the Brazilian state of Pernambuco

\begin{tabular}{lllll}
\hline Morphometric indices $^{1}$ & Stallions & Mares & Geldings & P-value \\
\hline ACW $(\mathrm{kg})$ & $448.3 \pm 39.95^{\mathrm{ab}}$ & $455.5 \pm 44.48^{\mathrm{a}}$ & $444.5 \pm 43.96^{\mathrm{b}}$ & 0.0351 \\
HAC $(\mathrm{m})$ & $0.814 \pm 0.04^{\mathrm{a}}$ & $0.799 \pm 0.03^{\mathrm{b}}$ & $0.802 \pm 0.03^{\mathrm{b}}$ & $<0.0001$ \\
CI $(\mathrm{m})$ & $-0.194 \pm 0.04^{\mathrm{b}}$ & $-0.181 \pm 0.04^{\mathrm{a}}$ & $-0.184 \pm 0.04^{\mathrm{a}}$ & 0.0043 \\
BI $^{*}$ & $0.891 \pm 0.03^{\mathrm{a}}$ & $0.886 \pm 0.03^{\mathrm{ab}}$ & $0.883 \pm 0.03^{\mathrm{b}}$ & 0.0325 \\
DTI $^{*}$ & $0.1103 \pm 0.01^{\mathrm{a}}$ & $0.1069 \pm 0.01^{\mathrm{b}}$ & $0.1107 \pm 0.01^{\mathrm{a}}$ & $<0.0001$ \\
CFI $^{*}$ & $2.096 \pm 0.11^{\mathrm{b}}$ & $2.139 \pm 0.11^{\mathrm{a}}$ & $2.093 \pm 0.12^{\mathrm{b}}$ & 0.0001 \\
LI1 $(\mathrm{kg})$ & $117.4 \pm 6.09^{\mathrm{b}}$ & $119.8 \pm 6.37^{\mathrm{a}}$ & $117.2 \pm 6.66^{\mathrm{b}}$ & 0.0001 \\
LI2 $(\mathrm{kg})$ & $199.1 \pm 10.33^{\mathrm{b}}$ & $203.2 \pm 10.80^{\mathrm{a}}$ & $198.8 \pm 11.29^{\mathrm{b}}$ & 0.0001
\end{tabular}

*Non-dimensional index. ${ }^{1}$ Approximate calculated weight (ACW). height at chest (HAC). chest index (CI). body index (BI). dactylthoracic index (DTI). conformation index (CFI). load index 1 (LI1). and load index 2 (LI2); P = P value; CV = coefficient of variation. Different small letters in the lines differ according to Dunn's test $(\mathrm{P}<0.05)$.

Different capital letters in the lines differ according to Tukey test $(\mathrm{P}<0.05)$.

The information provided by the horse owners during the interviews revealed that 1.271 $(60.84 \%)$ animals had won at least once in one of the four vaquejada classes (aspirant, amateur, intermediate, or professional). Regarding other finishing positions, $48.28 \%$ of the horses had reached at least once the second place; $41.26 \%$, third place; $33.03 \%$, fourth place; and $28.25 \%$, fifth place.

Since esteira horses are paired with different puxador horses. i.e., they compete more times in a single competition, the former would in 
theory have higher odds of winning. However, the frequency distribution test showed no difference $(\mathrm{P}$ $=0.4643$ ) in the percentage of esteira and puxador horses that had been champions. with rates of $63.08 \%$ and $59.78 \%$, respectively, having won a vaquejada trial at least once.

About the duration of vaquejada horses training, $93.3 \%$ of the animals underwent physical training 12 months a year. i.e., rest periods occurred only on special occasions such as when the horses had health issues that required rest. In addition to the animals being trained throughout the year, the owners of $27.5 \%$ of the horses in the study declared training them seven days a week. Only $7.1 \%$ of the animals trained six times a week, $25.6 \%$ trained five times a week, $8.4 \%$ trained four times a week, $17.3 \%$ trained three times a week, $12 \%$ trained twice a week and $2.1 \%$ trained a single time a week.

The training protocols adopted consisted of exercises ranging from $30 \mathrm{~min}$ to $4 \mathrm{~h}$ per day. However, most respondents trained their animals for up to $2 \mathrm{~h}$ per day: $25 \%$ of the horses trained for 30 min per day, $35 \%$ exercised for $1 \mathrm{~h}$, and $27 \%$ trained for $2 \mathrm{~h}$ per day.

Overall, the training sessions comprised activities in vaquejada tracks with bovines and exercises in external areas, usually roads outside the property, where the animals exercised walking, trotting, and galloping. When the horses reached sufficient fitness and technique to compete, training became constant in intensity and duration over the years.

\section{DISCUSSION}

The small number of foals. i.e., horses between two and three years old, found in the present study can be explained by the rules of the Associação Brasileira de Criadores de Cavalo Quarto de Milha (Brazilian Association of Quarter Horse Breeders - ABQM), which set the minimum age of five horse years for the animals to compete in the first official category, called Potro do Futuro (Foal of the Future) (ABVAQ, 2017). Among the modalities overseen by the ABQM, vaquejada is the sport that requires the highest initial age since it demands great physical strength and developed bone, tendon, and muscle structures, which are rarely seen in younger horses.

Vaquejada horses between four and ten years old were also observed by Boakari et al. (2009), who recorded a mean age of 7.94 years. That is because, unlike other equestrian modalities such as dressage, in which the animals reach maximum performance after ten years old, the intense and tiresome routine of vaquejada trials lead to a high incidence of injuries and, consequently, early retirement of horses (SOUSA, 2012). Corroborating this idea, Boakari et al. (2009) reported that $85.3 \%$ of vaquejada horses have orthopedic alterations.

The prevalence of Quarter Horses in vaquejada $(98.3 \%$ of the animals between pure and crossbred) is due to the physical qualities of the breed. These horses are extremely docile and strong and are capable of intense starts, sudden stops, and quick changes in direction, besides having a sharp instinct to work with bovines. According to Meneses et al. (2014), such characteristics, largely favored by the physical conformation of Quarter Horses, result in high performance in vaquejada contests. Moreover, the ABQM acknowledges vaquejada as a sport and supports it through official competitions.

Since most top finishers are Quarter Horses and most official events are supported by the ABQM, the consolidation of functional characteristics for the sport is more visible in animals of this breed. Thus, breeds such as Appaloosa and Paint Horse, whose selection processes also take into account genes with little connection with function such as those related to the coat, have inferior mean performance, which makes them lose ground to Quarter Horses.

English Thoroughbred horses are little used in vaquejada since, despite being quick and reaching mean speeds of $65 \mathrm{~km} / \mathrm{h}$ (SPENCE et al., 2012), they are selected for racing longer distances than the vaquejada track, favoring resistance over explosion, the latter an essential characteristic for the sport. On the other hand, the Quarter Horse breed, in addition to having race lineages that reach close to $90 \mathrm{~km} / \mathrm{h}$, also have quick starts, better maneuverability, and ability to work with bovines (ELLERSIECK et al., 1985).

In the present study, the measurements of width and height, except for height at side of the back, showed that the stallions had larger body dimensions than the mares and geldings. Larger linear measures in stallions competing in vaquejada may be related to the recent quest for larger, stronger animals in face of the increase in weight of bovines and the closer competition in vaquejada circuits in the Northeast.

Pimentel et al. (2011) measured vaquejada horses in the state of Rio Grande do Norte and reported similar body weight values between males and females at $438.63 \mathrm{~kg}$ and $437.04 \mathrm{~kg}$, respectively. Meneses et al. (2014), when working with the morphometric measures of 98 vaquejada 
Quarter Horses in the state of Minas Gerais, found mean calculated weight of $470 \mathrm{~kg}$. In the present study, most of the approximate body weight of mares compared to geldings can be explained by the formula that estimates this measure since it takes into account the thoracic circumference, which, in turn, is influenced by the body score and gestational status of females.

According to Lucena et al. (2015) the height at chest is associated with body stability in horses since it is related to the distance between the center of gravity of the animal and the ground. The closer to the ground the center of gravity, the more pulling force, agility, and motor coordination the horse will have. However, care must be exercised when seeking horses with excessively deep chest since they usually have short limbs with low biomechanical efficiency in running. Unlike draft horses, whose chests are excessively deep, and race horses, whose chest index values tend to be well below zero, horses used in sports that require agility, explosion, and speed should have height at chest little above the height at side of back. Thus, although the chest index values found in the present study have classified the stallions, mares, and geldings as being away from the ground, the animals had the desired balance for the role since such values were close to zero.

The body indices of the stallions, mares, and geldings classified them as mediolinear. This contrasts with Pimentel et al. (2011) and Meneses et al. (2014), who, based on the body index, classified vaquejada horses as compact. The quest for larger and stronger vaquejada horses may justify the different classification of the animals measured in the present study compared with those analyzed in previous works. In addition, mediolinear horses have better ratios between body length and thoracic circumference, which is a desirable condition in equestrian modalities that require agility and strength.

The dactyl-thoracic index takes into account the ratio between the circumferences of the cannon and thorax to assess whether the bone structure is appropriate to the body weight of the animal. The dactyl-thoracic indices of the stallions of 0.1103 and of the geldings of 0.1107 classify them as hypermetric. This characteristic is desired in vaquejada horses as it indicates good bone structure to carry the weight of the rider, to withstand the physical effort on a track covered in sand, and to be able to bring the bovine to the ground with lower risk of injury due to the heavy loads inherent to the sport.
The conformation index, which relates the thoracic circumference and the height at withers in horses, is used to differentiate saddle and draft animals. In the present study, the conformation indices of the stallions and geldings were below 2.1125, which classifies them as sports horses in accordance to the physical type expected for vaquejada horses. On the other hand, the conformation index of 2.139 calculated for the mares classifies them as draft animals, likely due to the larger thorax circumference.

Load index 1 indicates the weight $(\mathrm{kg})$ the animal can withstand without excessive effort on the back while trotting or galloping. Load index 2 indicates the weight $(\mathrm{kg})$ the animal can withstand without excessive effort on the back while walking. In both indices, the mares showed greater loadcarrying capacity with no excessive effort on the back while walking, trotting, or galloping than the stallions and geldings.

The joint analysis of all morphometric indices calculated showed empirical selection by the vaquejada horse breeders, who seek animals with larger dimensions in individual parts. This is likely because the new format of vaquejada competitions requires greater load and athletic capacities from the animals.

The prevalence of horses competing as puxador (70\%) compared to esteira (30\%) may be related to the greater demand for and valuation of the former. At the beginning of training, the owners first test the animals in the role of puxador. Only those who do not show the ability to compete as puxador are trained as esteira. Moreover, esteira horses may assist both right-side and left-side puxador animals and they are paired with different animals in a single event, thus they compete in more runs than their puxador counterparts. That allows the owners to take several puxador horses but only one or two esteira ones to the vaquejada contests.

The high frequency of competition $(79.7 \%$ of the horses competed between two and four times a month) may be associated with two factors: The large sums involved in the contests and the expression "vaquejada, more than a sport, a lifestyle," which is increasingly repeated by those involved with the sport. Thus, the aspiration of notoriety and prizes. reserved to the winners only, allied with the concept of vaquejada as an ideal of life, widely celebrated in song and social circles, both in person and online, likely overcomes the basic principles of rational use of the horses.

Based on the reasoning that the more they compete, the higher their chances of winning, the high frequency of participation in vaquejada 
contests may also justify the large proportion of animals that had already reached the top places in the trials. It is worth pointing out that the high frequency of competitions, besides increasing the odds of a victory also results in greater physical burden on the animals, which raises the risk of physical wear and injuries as well as behavioral alterations.

The lower frequency of participation in unofficial vaquejada contests is partially because of the small financial return offered by the polls. In face of the high expenses in rearing, training, and competition, breeders must raise capital to help offset the costs. The production and commercialization of foals in auction or even at the property, as well as the sale of semen, eggs, and embryos, are among the most common ways vaquejada horse owners use to make the activity financially viable.

Another way of garnering funds is to reach the top positions in the trials and, thus, to receive the prizes offered usually motorcycles, cars, or money. Since the prizes vary according to the size, scope, and importance of the vaquejada event (LIMA et al., 2006), the number of participants in unofficial circuits tends to be lower than in official ones due to the low value of the prizes, which makes the event little attractive. In official circuits, both the prizes and the recognition achieved by the winners are significant, which attracts hundreds of pairs.

Horse training involves regular periods of exercise and rest that promote structural and functional changes in the animal so that it can compete more efficiently. The adaptations take place in the cardiovascular system, in the muscle cells, and in structural elements such as bones and tendons. An efficient response depends on the stimulus caused by training (EVANS, 2000). Each animal must be trained according to its temperament and exercising capacity. However, irrespective of the sport, some common principles may compromise the athletic capacity of the animal if they are not followed whether for lack of physical preparation or excess workload.

Since $79.7 \%$ of the horses assessed took part in vaquejada contests two or more times a month, $93.3 \%$ of the horses trained 12 months a year, and $60.2 \%$ undergo fitness training between five and seven days a week, it can be assumed that the high incidence of orthopedic lesions in vaquejada horses (BOAKARI et al. , 2009; OLIVEIRA et al., 2011) is associated with the high intensity of training to which they are submitted.

\section{CONCLUSIONS}

The results show a predominance of Quarter Horses between four and ten years old in the vaquejada contests in Pernambuco and that the trials require the selection of physically larger and stronger stallions. In addition, the animals are submitted to intense training and competition routines.

\section{ACKNOWLEDGEMENTS}

The authors thank the Coordination for the Improvement of Higher Education Personnel (CAPES) for the master's scholarships.

RESUMO: O estudo objetivou determinar as faixas etárias, raças e características morfológicas dos equinos competidores de vaquejadas em Pernambuco, assim como definir a frequência em que os animais competem, os resultados conquistados nas disputas e a duração dos treinamentos. Foram utilizados 1271 equinos participantes de provas de vaquejada realizadas no sertão e agreste pernambucano. A primeira etapa do trabalho consistiu em uma entrevista aos proprietários dos animais para obter informações sobre a idade dos equinos, raça, circuitos de vaquejada em que competem (oficiais ou não oficiais), frequência de participação em vaquejadas, resultados alcançados nas provas e a duração mensal, semanal e diária dos treinamentos. $\mathrm{Na}$ segunda etapa foram mensuradas 15 medidas lineares e calculados oito índices morfométricos. Os dados obtidos a partir das entrevistas foram submetidos à análises estatísticas descritivas. Já as medidas lineares e índices morfométricos foram utilizados para comparar os sexos, por meio de delineamento experimental inteiramente ao acaso. Os resultados morfométricos foram submetidos à análise de variância e as médias comparadas pelo teste de Tukey $(\mathrm{P}<0,05)$. Observou-se que $80,3 \%$ dos equinos de vaquejada tinham entre quatro e 10 anos de idade e que $89 \%$ dos animais eram da raça Quarto de Milha. Em relação às medidas morfométricas, registrou-se nos garanhões maiores alturas na cernelha, dorso e garupa e maiores larguras de cabeça, peito e garupa que nas éguas e nos machos castrados. Por outro lado, dentre os oito índices calculados, apenas o valor do vazio subesternal dos garanhões foi superior as médias das fêmeas e dos machos castrados. Constatou-se que $79,7 \%$ dos equinos participavam de duas a quatro provas de vaquejada por mês e que $93,3 \%$ dos animais eram condicionados fisicamente 12 meses por ano. Concluiu-se que nas vaquejadas realizadas no 
estado de Pernambuco há predomínio de equinos da raça Quarto de Milha, na faixa etária entre quatro e dez anos e as provas exigem seleção de garanhões fisicamente maiores e mais fortes. Além disso, os animais são submetidos a intensas rotinas de competições e treinamento.

PALAVRAS-CHAVE: Cavalo. Competições. Equus caballus. Índices morfométricos. Treinamento.

\section{REFERENCES}

ASSOCIAÇÃO BRASILEIRA DE VAQUEJADA (ABVAQ). Regulamento Geral de Vaquejada 2017 - 2018. ABVAQ. João Pessoa: ABVAQ. 2017, 15 p. Disponível em: < https://

nucleos.nyc3.digitaloceanspaces.com/abvaq/documentos/regulamentogeraldevaquejada20172018.pdf $>$. Acesso em: 21 de abril de 2017.

BOAKARI, Y. L.; LEAL, A. B. G.; MARQUES, A. L. A.; ARRIVABENE, M. Ocorrência de tenossinovite em equinos de vaquejada no município de Teresina, PI, Brasil. In: CONGRESSO BRASILEIRO DE MEDICINA VETERINÁRIA. 36., 2009, Porto Seguro. Anais... Porto Seguro: Sociedade Brasileira de Medicina Veterinária, 2009.

BRETAS, M. S.; BERGMANN, J. A. G.; PROCÓPIO, A. M. Descrição dos pontos anatômicos para a tomada de medidas lineares e angulares nos equinos da raça Mangalarga Marchador. In: SEMANA DE INICIAÇÃO CIENTÍFICA DA UFMG, 2003. Belo Horizonte. Anais... Belo Horizonte: Universidade Federal de Minas Gerais, 2003.

ELLERSIECK, M. R.; LOCK, W. E.; VOGT, D. W.; AIPPERSPACH, R. Genetic evaluation of cutting scores in horses. Equine of Veterinary Science, Suwon, v. 5, n. 5, p. 287-289, 1985. https://doi.org/10.1016/S07370806(85)80066-6

EVANS, D. L. Exercise testing in the field. In: HINCHCLIFF, K. W. et al. Equine Exercise Physiology - The Science of Exercise in the Athletic horse. Philadelphia: Elsevier, 2000, p.10-32.

FELIX, F. K. L.; ALENCAR, F. A. G. O vaqueiro e a vaquejada: do trabalho nas fazendas de gado ao esporte nas cidades. Revista Geográfica de América Central, Heredia, v. 1, n. 1, p. 1-13, 2011.

LAGE, R. A.; QUEIROZ, J. P. A. F.; SOUSA, F. D. N.; AGRA, E. G. D.; REGINA, V. C. D. Fatores de risco para a transmissão da anemia infecciosa equina, leptospirose, tétano e raiva em criatórios equestres e parques de vaquejada no município de Mossoró, RN. Acta Veterinária Brasílica, Natal, v. 1, n. 3, p. 84-88, 2007. https://doi.org/10.21708/avb.2007.1.3.459

LIMA, R. A. S. et al. Estudo do complexo do agronegócio cavalo. Piracicaba: CEPEA/ESALQ/USP, 2006.

LIMA, R. A. S. et al. Revisão do Estudo do Complexo do Agronegócio do Cavalo. Brasília: MAPA, 2016.

LOPES, K. R. F.; BATISTA, J. S.; DIAS, R. V. C.; SOTO-BLANCO, B. Influência das competições de vaquejada sobre os parâmetros indicadores de estresse em equinos. Ciência Animal Brasileira, Goiânia, v. 10, n. 2, p. 538-543, 2009.

LUCENA, J. E. C.; VIANNA, S. A. B.; BERBARI NETO, F.; SALES FILHO, R. L. M.; DINIZ, W. J. S. Caracterização morfométricas de fêmeas, garanhões e castrados da raça Campolina baseada em índices. Arquivo Brasilerio de Medicina Veterinária e Zootecnia, Belo Horizonte, v. 68, n. 2, p. 431-438, 2016. http://dx.doi.org/10.1590/1678-4162-8016

MELO, U. P.; SANTIAGO, R. M. F. W.; BARRÊTO JÚNIOR, R. A.; FERREIRA, C.; BEZERRA, M. B.; PALHARES, M. S. Biometria e alterações do equilíbrio podal em equinos utilizados em vaquejada. Acta Veterinária Brasílica, Natal, v. 5, n. 4, p. 368-375, 2011. https://doi.org/10.21708/avb.2011.5.4.2261 
MENESES, A. C. A.; COSTA, M. D.; MARUCH, S.; MOREIRA, P. R.; MARTINS NETO, T. Medidas lineares e angulares de animais da raça Quarto de Milha em uma prova de vaquejada. Revista Brasileira de Ciência Veterinária, Niterói, v. 21, n. 4, p. 256-261, 2014. http://dx.doi.org/10.4322/rbcv.2015.306

OLIVEIRA, P. G. G.; ALVES, A. L. G.; CARVALHO, A. M.; HUSSNI, C. A.; WATANABE, M. J.; AMORIM, R. L.; RODRIGUES, M. M. P.; MOTA, L. S. Uso de células mononucleares da medula óssea no tratamento de tendinites induzidas experimentalmente em equinos. Arquivo Brasilerio de Medicina Veterinária e Zootecnia, Belo Horizonte, v. 63, n. 6, p. 1391-1398, 2011. http://dx.doi.org/10.1590/S010209352011000600016

OOM, M. M.; FERREIRA, J. C. Estudo biométrico do cavalo Alter. Revista Portuguesa de Ciência Veterinária, Lisboa, v. 82, n. 482, p. 101-148, 1987.

PIMENTEL, M. M. L.; CÂMARA, F. V.; DANTAS, R. A.; FREITAS, Y. B. N.; DIAS, R. V. C.; SOUZA, M. V. Biometria de equinos de vaquejada no Rio Grande do Norte, Brasil. Acta Veterinária Brasílica, Natal, v. 5, n. 4, p. 376-379, 2011. https://doi.org/10.21708/avb.2011.5.4.2322

RIBEIRO, D. B. O cavalo: raças, qualidades e defeitos. 2.ed. São Paulo: Editora Globo, 1989.

SOUSA, G. G. Q. Prevalence of Orthopedic Injuries in Athletes of Rodeo Brazilian (Vaquejada). International Journal of Sports Science, New York, v. 2, n. 2, p. 11-15, 2012. http://dx.doi.org/10.1590/S010132892011000100014

SPENCE, A. J.; THURMAN, A. S.; MAHER, M. J.; WILSON, A. M. Speed, pacing strategy and aerodynamic drafting in Thoroughbred horse Racing. Biology Letters, Sheffield, v. 8, n. 4, p. 678-681, 2012.

https://doi.org/10.1098/rsbl.2011.1120

TORRES, A. D. P; JARDIM, W. R. Criação do cavalo e de outros equinos. São Paulo: Editora Nobel, 1992. 